\title{
Clinical and Bacteriological Effects of Rifampicin in Combination with L73A in Leprosy: Observation for Six Months
}

\author{
SEIJI INNAMI \\ Leprocomio Santa Isabel, Sapucay, Paraguay \\ OSCAR R. LEGUIZAMŌN \\ Centro de Salud No. 1., Asuncion, Paraguay \\ and \\ ARNALDO E. ALVARENGA \\ Departamento de Lepra, Ministerio de Salud Publica y \\ Bienestar Social, Asunción, Paraguay

\begin{abstract}
Therapeutic effects of rifampicin in combination with L73A were observed both clinically and bacteriologically in 30 patients with lepromatous leprosy for 6 months.

It was evident that the fall of BI was gradual and the decrease of MI was rapid in practically all cases. One of the most favourable signs of clinical improvement was the flattening and absorption of nodules and other raised skin lesions in a short time. ENL was observed in about $33 \%$, mild dizziness was seen frequently as a side effect.
\end{abstract}

\section{Introduction}

At the request of Prof. Freerksen, treatment with rifampicin in combination with L73A was carried out in 30 selected lepromatous leprosy patients for a period of 6 months. All other anti-leprosy drugs were stopped for 1 month before the start of administration. Daily dosage of $600 \mathrm{mg}$ rifampicin and 4 tablets of L73A were administered orally except on Sunday.

Twenty-six out of 30 cases completed the scheduled treatment for 6 months. Four cases were suspended from the trial for various reasons.

\section{Results}

Changes of BI and MI of Myco. leprae during rifampicin and L73A therapy

These are shown in Table 1.

The fall of BI was gradual in all cases, and 3 out of 30 cases became 
bacteriologically negative at 6 months. On the other hand the MI decreased very rapidly. The improvement in MI was seen in almost all cases within 3 months, and the average value of MI decreased from $12.6 \%$ to $5.0 \%$ at 6 months.

TABLE 1

The changes of $B I$ and $M I$ of $\mathrm{Myco}$. leprae treated with rifampicin and $L 73 \mathrm{~A}$

\begin{tabular}{|c|c|c|c|c|c|c|}
\hline \multirow{3}{*}{$\begin{array}{l}\text { Patients } \\
\text { number }\end{array}$} & \multicolumn{6}{|c|}{ Months of treatment } \\
\hline & \multicolumn{2}{|c|}{ Initial } & \multicolumn{2}{|c|}{3 months } & \multicolumn{2}{|c|}{6 months } \\
\hline & $\mathrm{BI}+$ & $\mathrm{MI} \%$ & $\mathrm{BI}+$ & $\mathrm{MI} \%$ & $\mathrm{BI}+$ & MI\% \\
\hline 1 & 5 & 15 & 5 & 11 & 5 & 9 \\
\hline 2 & 3 & 4 & 2 & 3 & 2 & 1 \\
\hline 3 & 4 & 12 & 4 & 6 & 3 & 5 \\
\hline 4 & 2 & 7 & 1 & 1 & 0 & 0 \\
\hline 5 & 5 & 18 & 5 & 7 & - & \\
\hline 6 & 5 & 23 & 4 & 10 & 4 & 7 \\
\hline 7 & 3 & 6 & 2 & 2 & 2 & 2 \\
\hline 8 & 3 & 9 & 3 & 5 & 2 & 5 \\
\hline 9 & 5 & 31 & 4 & 18 & 4 & 7 \\
\hline 10 & 3 & 12 & - & - & $\approx$ & - \\
\hline 11 & 3 & 7 & 3 & 5 & 2 & 5 \\
\hline 12 & 3 & 8 & 2 & 5 & 2 & 5 \\
\hline 13 & 5 & 16 & 5 & 9 & 4 & 6 \\
\hline 14 & 5 & 25 & 4 & 12 & 4 & 15 \\
\hline 15 & 3 & 6 & 1 & 2 & 0 & - \\
\hline 16 & 4 & 18 & 4 & 11 & 3 & 7 \\
\hline 17 & 4 & 17 & 4 & 12 & 3 & 8 \\
\hline 18 & 5 & 21 & 5 & 11 & 5 & 9 \\
\hline 19 & 4 & 6 & 4 & 3 & 3 & 3 \\
\hline 20 & 4 & 14 & 4 & 8 & 4 & 6 \\
\hline 21 & 2 & 4 & 2 & 0 & 0 & 0 \\
\hline 22 & 4 & 13 & 3 & 7 & 3 & 5 \\
\hline 23 & 3 & 9 & 3 & 5 & 2 & 5 \\
\hline 24 & 4 & 9 & - & - & - & - \\
\hline 25 & 4 & 9 & 4 & 6 & 3 & 5 \\
\hline 26 & 3 & 7 & - & - & - & \\
\hline 27 & 3 & 8 & 3 & 3 & 2 & 2 \\
\hline 28 & 5 & 23 & 3 & 11 & 3 & 7 \\
\hline 29 & 4 & 13 & 4 & 8 & 3 & 3 \\
\hline 30 & 3 & 7 & 3 & 5 & 3 & 3 \\
\hline Average & 3.8 & 12.6 & 3.4 & 6.9 & 2.7 & 5.0 \\
\hline
\end{tabular}

\section{Clinical results}

$\begin{array}{lr}\text { Effective } & 15 \text { cases } \\ \text { Unchanged } & 14 \text { cases } \\ \text { Worse } & 0 \text { case } \\ \text { Dead } & 1 \text { case } \\ \text { Total } & 30 \text { cases }\end{array}$

One of the most striking signs of clinical improvement was the flattening and absorption of nodules and other raised skin lesions within 6 months. 


\section{ENL during the treatment}

Ten patients experienced ENL while under treatment.

$\begin{array}{ll}\text { Severe ENL } & 4 \text { cases } \\ \text { Mild ENL } & 6 \text { cases }\end{array}$

All cases were controlled by thalidomide or by diminished dosage of L73A.

\section{Side effects during the treatment}

Side effects were observed in 11 cases.

$\begin{array}{ll}\text { Mild dizziness } & 6 \text { cases } \\ \text { Gastric disturbances } & 2 \text { cases } \\ \text { Headache } & 2 \text { cases } \\ \text { Pruritus } & 1 \text { case } \\ \text { Total } & 11 \text { cases }\end{array}$

These side effects frequently occurred after the pause of administration on Sunday.

Tolerance and non-tolerance of rifampicin and L73A

$\begin{array}{lr}\text { Tolerance } & 26 \text { cases } \\ \text { Non-tolerance } & 4 \text { cases } \\ \text { Total } & 30 \text { cases }\end{array}$

Rifampicin and L73A treatment had to be interrupted in 4 cases for the following reasons:

Severe iridocyclitis in 1 case, epilepsy-like seizure in 1 case, severe polyneuritis in 1 case, and death in 1 case. The patient who died had been suspended from treatment for 1 week because of ENL after 2 months of treatment. Death with some symptoms of toxicity occurred shortly after the intake of rifampicin and L73A after the pause of administration.

\section{Laboratory examinations}

$\begin{array}{ll}\text { Increase of SGOT and GPT } & 2 \text { cases } \\ \text { Continued proteinuria } & 5 \text { cases } \\ \text { Severe signs of anaemia } & 1 \text { case } \\ \text { Total } & 8 \text { cases }\end{array}$

\section{Summary}

Therapeutic effects of rifampicin in combination with L73A were observed both clinically and bacteriologically on 30 patients with lepromatous leprosy for 6 months.

It was evident that the fall of BI was gradual and the decrease of MI was rapid in practically all cases. One of the most favourable signs of clinical improvement 
was that nodules and other raised skin elevations became absorbed and flattened out in a short time.

ENL was observed in about $33 \%$. Mild dizziness was seen frequently as a side effect. Careful attention must be paid to liver function, proteinuria and anaemia during the treatment.

Though we have no comparison with other control groups, the clinical and bacteriological results of the treatment indicate strongly that the best and rapid effects may be expected in cases of lepromatous leprosy with nodules or raised skin elevations.

\section{Acknowledgements}

We are greatly indebted for the cooperation of Dr Felipe Gimenez, Haematologist, Mrs G. Schrammen-Secretary of Department of Leprosy, Ministry of Health and Welfare, and nursessisters of Leprosarium Santa Isabel. 